\title{
Geologia Croatica \\ A response to the comment \\ of Roller-Lutz et al. on the paper by Lukač Reberski et al. published in Geologia Croatica 66/1, 39-53 (2013): "Definition of the river Gacka springs subcatchment areas on the basis of hydrogeological parameters"
}

Jasmina Lukač Reberski ${ }^{1}$, Tamara Marković ${ }^{1}$ and Zoran Nakić

${ }^{1}$ Croatian Geological Survey, Sachsova 2, Zagreb, Croatia

${ }^{2}$ University of Zagreb, Faculty of Mining, Geology and Petroleum Engineering, Pierottieva 6, 10000 Zagreb, Croatia

doi: 10.4154/gc.2013.13

As the authors of the above-mentioned paper in Geologia Croatica, issue 66/1, we felt the need to respond to the Comment made by Zvjezdana Roller-Lutz, Tamara Hunjak and Hans O. Lutz.

We would like to refer to the claims: A) that we took isotope data (D and 180) of springs for the year 2008 without consent, B) that isotope results were preliminary and shown only in an unpublished and not citable report, and C) that LMWL on fig. 7 is plotted incorrectly.

Ad A): In the paper Lukač Reberski et al. (2013), isotopic data are presented for the period from 2002 till 2008. The isotope analyses of spring waters from 2002 till 2006 are the result of investigations carried out for the master thesis of Jasmina Lukač Reberski (2008) which was a part of the project "Basic hydrogeological map of the Republic of Croatia 1:100 000" funded by the Croatian Ministry of Science, Education and Sports (Project number 181-18110963165), and CRO/8/006 project funded by IAEA-TC (International Atomic Energy Agency - Technical Cooperation) coordinated by the Ruđer Bošković Institute (report is available at: http://bib.irb.hr/prikazi-rad?\&rad=312123). The isotope analyses of spring waters for the year 2008 are the result of a cooperation project IAEA-TC CRO/8/007 coordinated by the University of Rijeka, Faculty of Medicine, in which the Croatian Geological Survey (CGS) also participated in a manner that researchers of the CGS performed field work (water sampling, discharge measurements and measurements of in situ physico-chemical parameters). They also measured water chemical parameters in their laboratory. Based on the verbal agreement between researchers of the project $\mathrm{CRO} / 8 / 007$, the preliminary isotope data of spring waters (only for the year 2008) were given to researchers from the CGS, for the purpose of writing the $\mathrm{PhD}$ thesis (Lukač Reberski, 2011). Since PhD theses are available to the public, any data contained therein cannot be considered confidential.

Ad B): The aim of the paper by Lukač Reberski et al. (2013) was to present the overview of the PhD thesis (Lukač Reberski, 2011) and new insights about the river Gacka springs catchment area. Furthermore, the University of Rijeka asked the researchers from the CGS to cite the published paper (Mandić et al., 2008) where the preliminary data were analysed. The mentioned paper was cited in the $\mathrm{PhD}$ thesis (Lukač Reberski, 2011) and also in the paper: Lukač Reberski et al. (2013). That is the reason why the stable isotope data were included in the paper, although it had minor influence to the conclusions.

Ad C) An unintentional error occurred in Figure 7 during the diagram construction due to which the graphical line that represents LMWL slightly moved from its original position. Here is corrected figure 7. However, the explanation for Figure 7 is cited from the paper Mandić et al., 2008. 


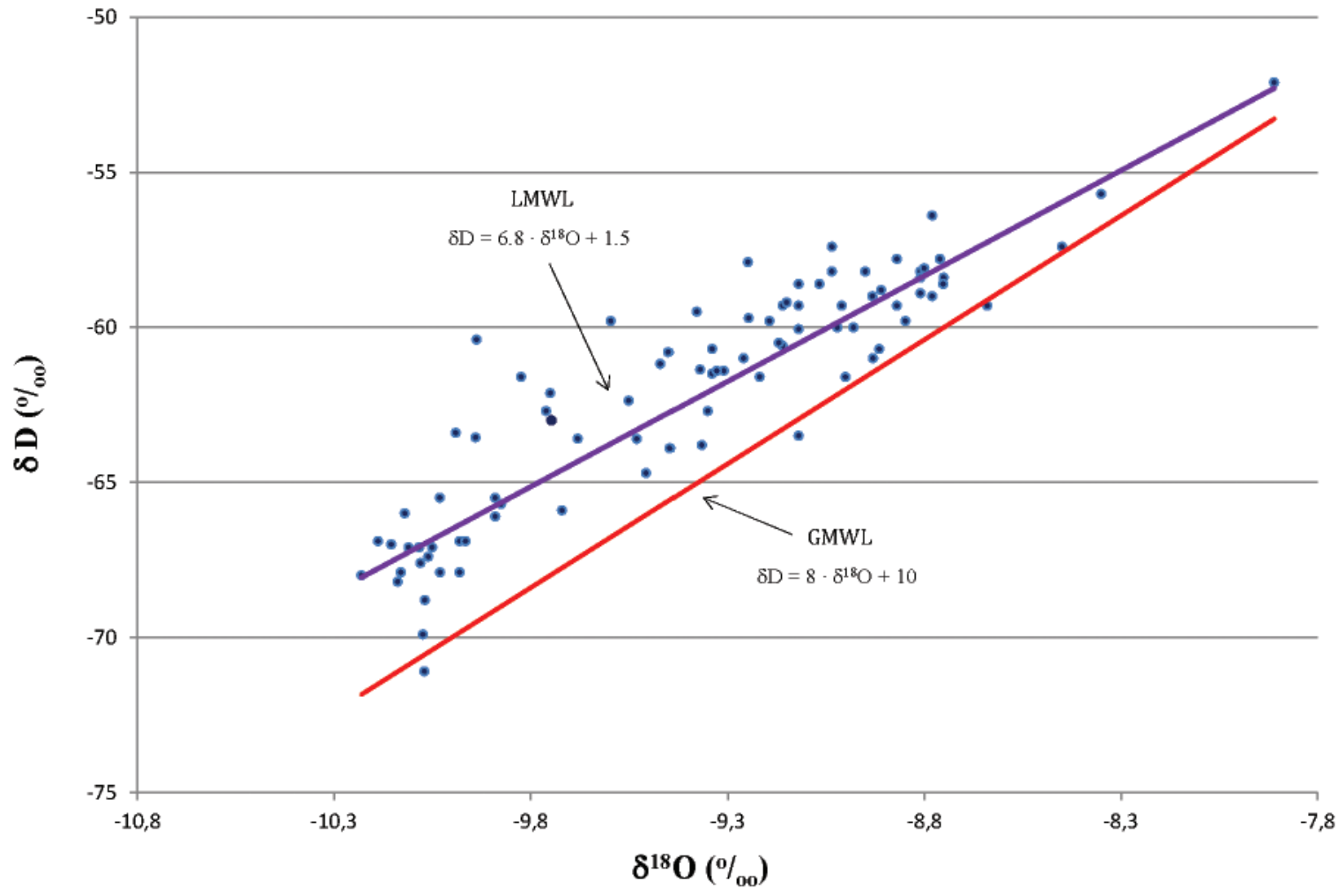

Figure 7: The ratio of oxygen-18 and deuterium stable isotopes in spring waters of the Gacka catchment.

\section{REFERENCES}

HORVATINČIĆ, N., ROLLER-LUTZ, Z., KAPELJ, S. (2007): Application of isotope techniques in investigation of water resources and water protection in the Karst area of Croatia (IAEA TC CRO/8/006) (final report).

LUKAČ REBERSKI, J, MARKOVIĆ, T., NAKIĆ, Z. (2013) Definition of the river Gacka springs subcatchment areas on the basis of hydrogeological parameters.- Geologica Croatica, 66/1, 39-53.

LUKAČ REBERSKI, J. (2011) Određivanje podsljevova izvorišta rijeke Gacke na osnovi hidrogeoloških parametara [Definition of the river Gacka springs subcatchment areas on the basis of hydrogeological parametars - in Croatian].- Doctoral Thesis. Rudarsko geološko naftni fakultet, Sveučilište u Zagrebu (Faculty of Mining, Geology and Petroleum Engineering, University of Zagreb), 158 p.

LUKAČ REBERSKI, J. (2008): Hidrogeološka i hidrogeokemijska osnova za definiranje slijeva Gacke i zaštita njenog izvorišta [Hydrogeological and hydrogeochemical basis for the catchment area definition: Gacka river springs catchment area - in Croatian].Master's Thesis. Rudarsko-geološko-naftni fakultet, Sveučilište u Zagrebu (Faculty of Mining, Geology and Petroleum Engineering, University of Zagreb), $118 \mathrm{p}$.

MANDIĆ, M., BOJIĆ, D., ROLLER-LUTZ, Z., LUTZ, H. \& BRONIĆ KRAJCAR, I. (2008): Note on the spring region of Gacka River (Croatia).- Isotop. Envir. Health Studies, 44/2, 201-208. doi: 10.1080/10256010802066364. 